Kalpa Publications in Engineering
Volume 1, 2017, Pages 354-364
ICRISET2017. International Conference on Re-
search and Innovations in Science, Engineering
\&Technology. Selected Papers in Engineering kalpe

\title{
Computational Analysis of Reciprocating Compressor Piston for Life Time Performance
}

\author{
Hiren K. Leuva ${ }^{1}$, Prof. S.A.Shah ${ }^{2}$, Prof. H.A.Bhargav ${ }^{3}$ \\ ${ }^{1}$ Student, M.Tech (Machine Design) 'Mechanical Engineering, BVM Engineering \\ College, Vallabh Vidyanagar, Gujarat, India \\ ${ }^{2,3}$ Mechanical Engineering, BVM Engineering College, Vallabh Vidyanagar, Gujarat, \\ India
}

\begin{abstract}
Piston in reciprocating compressor has to perform work until certain life. But piston fail because of improper design. The design of piston must be done for a life time performance. In this paper, the body of work is carried out to design the piston and measure the distribution of stress on the piston of reciprocating oil less gas booster compressor. The dimension of the piston is calculated by analytical method. According to this dimension solid model is developed using modeling software Creo Parametric 2.0. Then analysis is carried through using FEA based software ANSYS 15.0. The result stresses are compared with analytical calculation.
\end{abstract}

Keywords: Compressor, piston, stress analysis

\section{INRODUCTION}

A reciprocating compressor or piston compressor is positive-displacement type compressor that use piston driven by a crankshaft to deliver gases at higher pressure. The inlet pressure level can be vary from vacuum pressure to a high positive pressure. The discharge pressure can range from sub atmospheric levels to high values in the $10 \mathrm{~s}$ thousands of pounds per square inch. The fluid compressed can be any compressible fluid, either vapor or gas. Oil-less gas booster compressors are units that operate without any aid of oil lubrication[1]. The gas being compressed does not get in contact with an oil lubricant. The main requirement of a piston is a good sealing of gas between piston and the cylinder. Another is that the weight of the piston and the whole crank mechanism is a minimum, particularly for high speed machines, in order to bring down the inertia force and to improve the mechanical efficiency[3]. It is necessary to compute the stresses upon the piston in order to bring down the deformation within the acceptable limit. The stress analysis help us to optimise the design at lower cost, before the prototype would be

developed. The piston ring and skirt are generally of dry lubricant material such as carbon or a P.T.F.E. filled material. The Teflon material is in use as piston rings for lubrication purpose. Teflon having very low coefficient of friction and low thermal expansion neglects the necessity of oil lubrication. The connecting rod and gudgeon pin bearing are grease filled up and sealed off for life[2]. 
The paper will illustrate the piston design of oil less reciprocating compressor and static stress analysis of piston.

\section{DESIGN DATA FOR COMPRESSOR}

- Power requirement : $2 \mathrm{HP}$

- $\quad$ Capacity : 10 CFM

- Output pressure : 10 Bar

- $\quad$ Speed : 1440 RPM

- $\quad$ No. of stage : 1

The above parameter are considered for the design of the piston of the reciprocating compressor.

\section{DESIGN OF PISTON}

The piston is modeled as the procedure and spec which are reffered in machine design and data hand books[17]. The dimensions are calculated in terms of SI system Units.[17]. The dimensions are calculated in terms of SI Units. The pressure implemented upon piston head, temperatures of different area of piston, stresses, strains, heat flow, length, thicknesses, dia of the piston and hole, etc., parameters are taken into consideration[4].

\section{DESIGN CONSIDERATIONS FOR A PISTON}

In designing a piston for reciprocating compressor, the below points should be taken into consideration:

- It should have sufficient strength for withstanding the high pressure.

- It should have minimum weight to withstand the inertia forces.

- It should capable to form effective gas sealing in the cylinder.

- It should provide enough bearing area to prevent wear.

- It should have high speed reciprocation with no make noise.

- It should comprise of enough rigid construction to resist thermal and mechanical deformations due to stresses.

It had better support for the piston pin[16].

\section{PISTON MATERIAL}

Piston material should have better friction properties, high strength, and capable of producing better casting having good machining properties[5]. The thermal expansion coefficient is small as it is very important for compressed gas temperature, where good thermal conductivity is also required. 
TABLE 1 : Piston Material

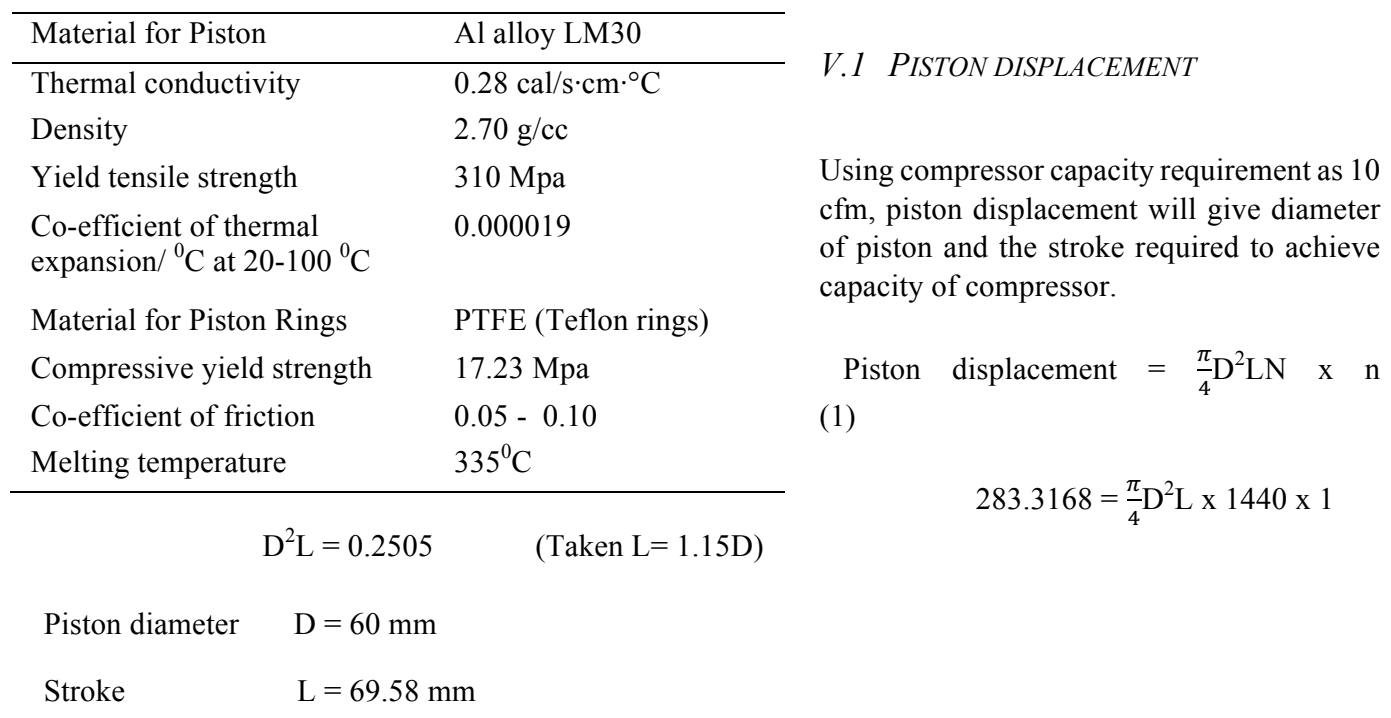

\section{V.2 THICKNESS OF PISTON HEAD $\left(T_{H}\right)$}

The piston thickness of piston head accounted utilising the below Grashoff's expression,

$$
\begin{aligned}
& \mathrm{t}_{\mathrm{h}}=\sqrt{\frac{3 P \max D 2}{16 \sigma t}} \\
& \mathrm{t}_{\mathrm{h}}=\sqrt{\frac{3 \times 1 \times 60 \times 60}{16 \times 155}} \\
& \mathrm{t}_{\mathrm{h}}=2.08 \mathrm{~mm}
\end{aligned}
$$

Thickness of the piston head also calculated by using Empirical formula,

$$
\begin{aligned}
& t_{\mathrm{h}}=0.032 \mathrm{D}+1.5 \\
& \mathrm{t}_{\mathrm{h}}=0.032(60)+1.5 \\
& \mathrm{t}_{\mathrm{h}}=3.42 \mathrm{~mm}
\end{aligned}
$$

\section{V.3 PISTON RINGS}

The piston rings are in use to impart the essential radial pressure to sustain the seal between the piston and cylinder bore. The radial thickness may be calculated by considering radial pressure between cylinder wall and the ring.

The radial width of the ring is calculated by

$$
\mathrm{t}_{1}=\sqrt{\frac{3 P w}{\sigma t}} \mathrm{D}
$$




$$
\begin{aligned}
& \qquad \mathrm{t}_{1}=\sqrt{\frac{3 \times 0.025}{17.23}} \times 60 \\
& \mathrm{P}_{\mathrm{w}}=\text { pressure of gas on cylinder wall taken as } 0.025 \mathrm{~N} / \mathrm{mm}^{2} \\
& \sigma_{\mathrm{t}}=17.23 \text { Mpa for Teflon ring material } \\
& \quad \mathrm{t}_{1}=3.95 \mathrm{~mm}
\end{aligned}
$$

\section{V.4 Axial THICKNESS of Ring $\left(t_{2}\right)$}

The thickness of the rings may be taken as,

$$
\mathrm{t}_{2}=0.7 \mathrm{t}_{1} \text { to } \mathrm{t}_{1}
$$

$$
\mathrm{t}_{2}=2.77 \text { to } 3.95 \mathrm{~mm}
$$

The minimum axial thickness may obtain by empirical relation,

Minimum axial thickness $\left(\mathrm{t}_{2}\right)$

$$
\begin{aligned}
\mathrm{t}_{2 \min }=\frac{D}{10 Z} & \text { where } Z=\text { number of rings }=2 \\
\mathrm{t}_{2 \min } & =\frac{60}{10 \times 2} \\
\mathrm{t}_{2 \min } & =3 \mathrm{~mm}
\end{aligned}
$$

\section{V.5 WIDTH OF THE TOP LAND $\left(H_{l}\right)$}

The width of the top land varies from

$$
\begin{aligned}
\mathrm{h}_{1} & =\mathrm{t}_{\mathrm{h}} \text { to } 1.2 \mathrm{t}_{\mathrm{h}} \\
\mathrm{h}_{1} & =4.104 \mathrm{~mm}
\end{aligned}
$$

Width of other lands (b2)

Width of other ring lands varies from

$$
\begin{aligned}
& \mathrm{h}_{2}=0.75 \mathrm{~h}_{1} \text { to } \mathrm{h}_{1} \\
& \mathrm{~h}_{2}=3.95 \mathrm{~mm}
\end{aligned}
$$

\section{V.6 MAXIMUM THICKNESS OF BARREL (T)}

The maximum thickness of piston barrel may be obtain by

$$
\begin{aligned}
& \mathrm{t}_{3}=0.03 * \mathrm{D}+\mathrm{b}+4.5 \mathrm{~mm} \\
& \mathrm{t}_{3}=10.65 \mathrm{~mm}
\end{aligned}
$$

The piston wall thickness towards open end

$$
\begin{aligned}
& \mathrm{t}_{4}=0.25 \mathrm{t}_{3} \text { to } 0.35 \mathrm{t}_{3} \\
& \mathrm{t}_{4}=3.72 \mathrm{~mm}
\end{aligned}
$$




\section{V.7 PISTON SKIRT}

The piston part below the ring section is called as skirt. It helps to bear the side axial thrust. The side thrust is normally taken as 0.1 to 0.3 of maximum pressure.

Maximum gas load on the piston,

$$
\mathrm{P}=\mathrm{p} \times \pi \mathrm{D}^{2} / 4
$$

Maximum side thrust on cylinder,

$$
\begin{aligned}
& \mathrm{R}=\mathrm{P} / 10 \\
& \mathrm{R}=0.1 \mathrm{p} \times \pi \mathrm{D}^{2} / 4
\end{aligned}
$$

The side thrust also given by,

$\mathrm{R}=$ bearing pressure $\mathrm{X}$ projected bearing area of piston skirt

$$
\mathrm{R}=\mathrm{p}_{\mathrm{b}} \times \mathrm{D} \times 1_{\mathrm{s}}
$$

By comparing both the equation length of the skirt can be calculated as,

$$
1_{\mathrm{s}}=62.20 \mathrm{~mm}
$$

\section{V.8 TOTAL LENGTH OF PISTON}

The length of the piston is the sum of piston skirt, ring section and top land.

$$
\begin{aligned}
& \mathrm{L}=\text { top land }+ \text { length of ring section }+ \text { length of skirt } \\
& \mathrm{L}=76.054 \mathrm{~mm}
\end{aligned}
$$

\section{V.9 PISTON PIN}

The piston pin is used to connect the piston and the connecting rod. The center of piston pin should be $0.02 \mathrm{D}$ to $0.04 \mathrm{D}$ above the center of skirt.

The outside diameter of piston ring is given by,

$$
\begin{gathered}
\mathrm{d}_{0}=0.4 \mathrm{D} \\
\mathrm{d}_{0}=24 \mathrm{~mm} \\
\mathrm{~d}_{\mathrm{i}}=0.6 \mathrm{~d}_{0} \\
\mathrm{~d}_{\mathrm{i}}=14.4 \mathrm{~mm}
\end{gathered}
$$

Length of the piston pin in bush of small end of the connecting rod is given by,

$$
\begin{aligned}
& \mathrm{l}_{1}=0.45 \mathrm{D} \\
& \mathrm{l}_{1}=27 \mathrm{~mm}
\end{aligned}
$$

The length between the support is given by,

$$
1_{2}=43.5 \mathrm{~mm}
$$


Computational Analysis of Reciprocating Compressor Piston Hiren Leuva, S A Shah, H A Bhargav

VI. ACCORDING TO MATHEMATICAL MODELING ALL THE DIMENSION OF THE PISTON WERE FOUND ABOVE.

THE DIMENSION OF THE PISTON ARE GIVEN IN THE BELOW TABLE IN MM.ANALYTICAL DESIGN OF PISTON

\begin{tabular}{cc}
\hline TABLE $2:$ Dimension of Piston \\
\hline Design dimension & $\begin{array}{c}\text { Size } \\
\text { in mm }\end{array}$ \\
\hline Cylinder bore / Outside diameter of & 60.00 \\
the piston $(\mathrm{D})$ & 3.42 \\
thickness of the Piston Head & 3.95 \\
Radial thickness of the ring $\left(\mathrm{t}_{1}\right)$ & 3.00 \\
Axial thickness of the ring $\left(\mathrm{t}_{2}\right)$ & 4.10 \\
Width of Top Land $\mathrm{h}_{1}$ & 3.95 \\
Ring Lands: $\mathrm{h}_{2}$ & 10.65 \\
Thickness of piston barrel at the Top & end: $\mathrm{t}_{3}$ \\
Thickness of piston barrel at the Open & 3.72 \\
end: $\mathrm{t}_{4}$ & 62.20 \\
Length of the skirt: $\mathrm{l}_{\mathrm{s}}$ & 27.00 \\
Length of piston pin in the connecting & rod bushing: $\mathrm{l}_{1}$ \\
Piston pin outside diameter: do & 24.00 \\
Piston pin inside diameter: $\mathrm{d}_{\mathrm{i}}$ & 14.40 \\
\hline
\end{tabular}

\section{CREO MODEL}

Using above dimensions of the piston, the 3D model is developed into the modeling software creo parametric 2.0.
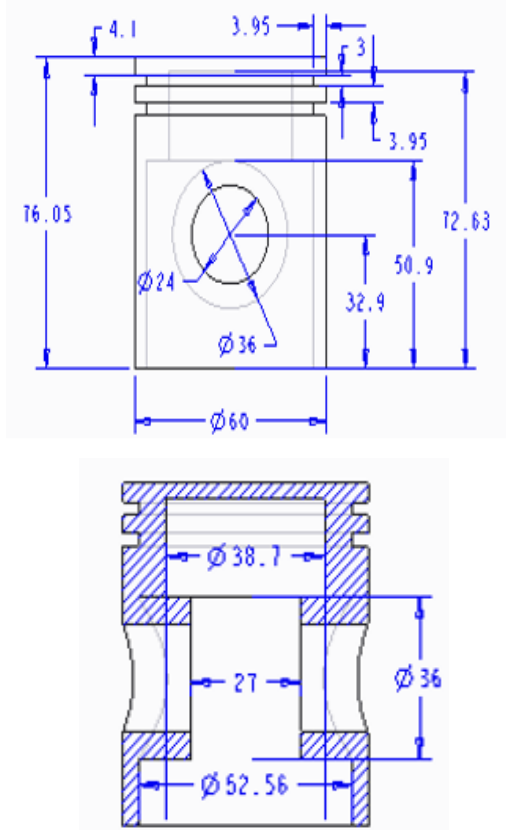

Fig 1 : Piston Dimension 


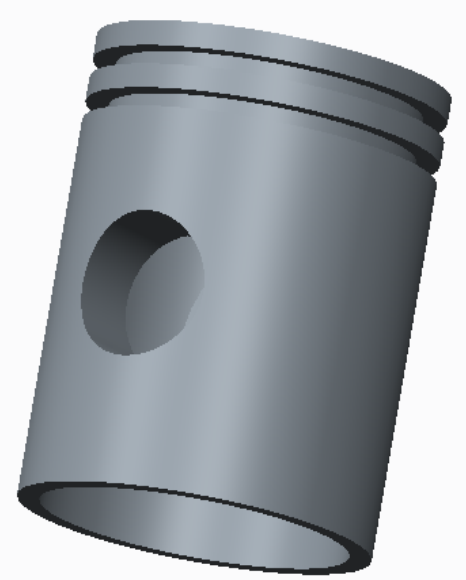

Fig 2 : Creo Model

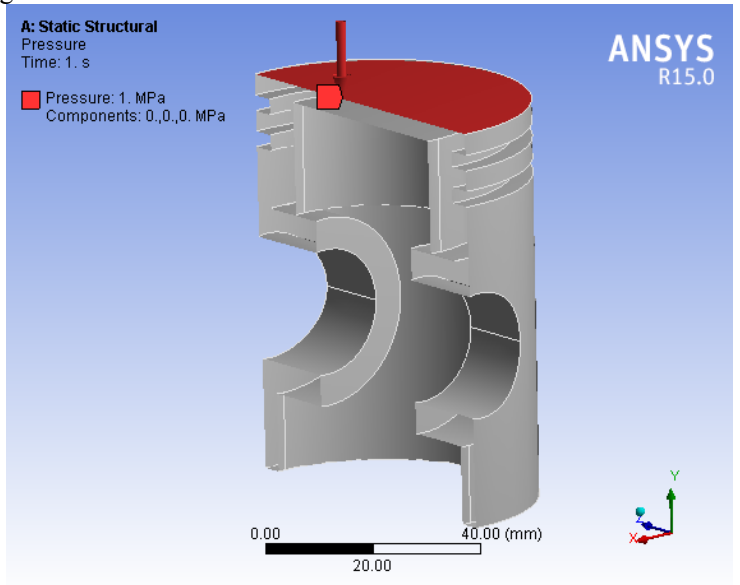

Fig 3 : Pressure load on piston head

- $\quad$ Frictionless support at pin bore areas and fixed all degree of freedom 
Computational Analysis of Reciprocating Compressor Piston Hiren Leuva, S A Shah, H A Bhargav

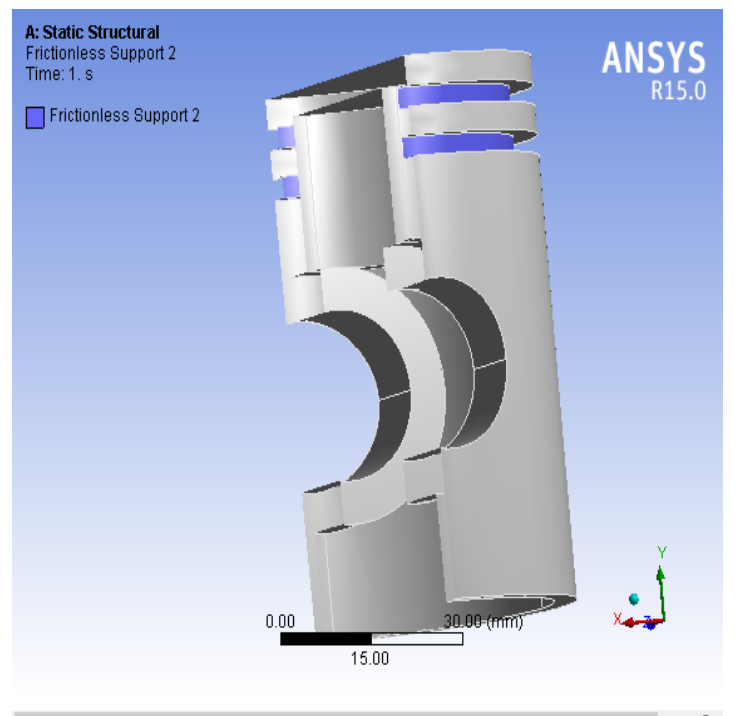

Fig 4 : Frictionless Support 1

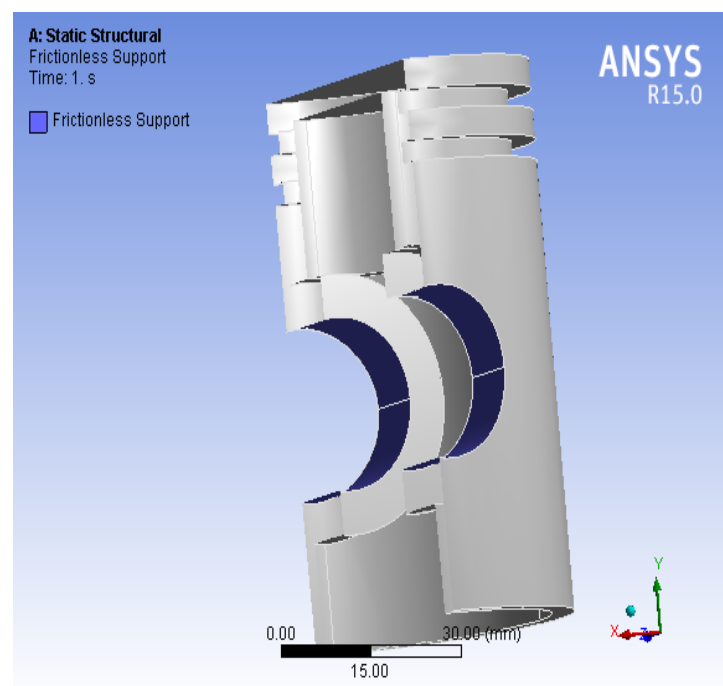

Fig 5 : Frictionless support 2

The friction less support at the piston rings will allow only linear reciprocating movement to the piston.

The value of von-mises stress are found by analysis and result is in following figure: 


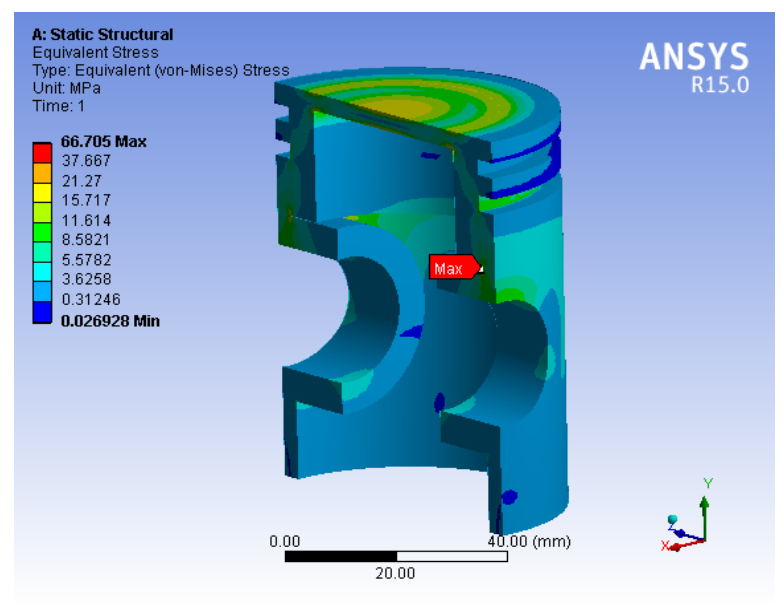

Fig 6 : Result of Stress Analysis

It can be seen from the static stress analysis of piston that the stresses produced during the operation are maximum at the piston pin contact area. The maximum von-mises stress developed is $66.705 \mathrm{Mpa}$ that is less as compared to the design stress $155 \mathrm{Mpa}$. The stresses at the top land and piston open end is much smaller than the design stresses. So at that area it is require to optimize the mass of piston maintaining the stresses value lower. At this level design is safe for this dimension.

\section{CONCLUSION}

Piston in reciprocating compressor has to perform work until certain life. But piston fail due to unsuitable design. Testing of piston failure for prediction of its life is possible with using modeling and analysis software. So that we can reduce the cost of testing. Here the piston is designed in modeling software Creo Parametric 2.0 and analysis is done using Ansys 15.0. The results predicted the stresses that will developed during its running condition can be reduced and life of piston can be improved.

\section{REFERENCES}

[1] Meece, Wayne, Otto Blank, and Charles W. Ickes. "Design of Oil-less Compressors and Pumps." (1974).

[2] Baumann, Heinz, and Martin Conzett. "Small oil free piston type compressor for $\mathrm{CO}_{2}$." (2002). 
Computational Analysis of Reciprocating Compressor Piston Hiren Leuva, S A Shah, H A Bhargav

[3] Jadhao, P. K., K. K. Jadhao, and S. S. Bhagwat. "Design, Modeling and Analysis Of Double Acting Reciprocating Compressor Components." International Journal of Scientific \& Engineering Research 3.4 (2012): 1 .

[4] Almasi, A. "Reciprocating compressor optimum design and manufacturing with respect to performance, reliability and cost." World Academy of Science, Engineering Technology, April 3 (2009).

[5] Aung, Wai Phyo, and Htay Htay Win. "Design and Analysis of Piston for Two Stages Reciprocating Air Compressor." (2014).

[6] Patel, Bhaumik, and Ashwin Bhabhor. "Thermal analysis of a piston of reciprocating air compressor." International Journal of Advanced Engineering Research and Studies E-ISSN2249-8974.

[7] Ajay raj singh, Dr. Pushpendra kumar sharma, "design, analysis and optimization of three aluminium piston alloys using fea", int. Journal of engineering research and applications issn : 2248-9622, vol. 4,(2014), pp.94102

[8] Tamrakar, Rohit, et al. "DESIGN OPTIMIZATION AND FINITE ELEMENT ANALYSIS OF PISTON USING PRO-e." International Journal of Mechanical Engineering and Robotics Research 3.2 (2014): 93.

[9] Rahul D. Raut, Satish Mishra," stress optimization of s.i. engine piston", international journal of science and research issn : 2319-7064

[10] Yadav, Vinod, and Dr DN Mittal. "Design and Analysis of Piston Design for 4 Stroke Hero Bike Engine." International Journal of Engineering Innovation \& Research 2.2 (2013): 148-150.

[11] Sheikh Naim Sheikh Yusuf, Nikhil D." Finite element analysis and optimization of piston using cae tools", international journal of mechanical and production engineering, issn: 2320-2092, volume- 3, issue-3, march2015

[12] Farzaneh Gord, M., A. Niazmand, and M. Deymi-DashteBayaz. "Optimizing reciprocating air compressor design parameters based on fi rst law analysis, UPB Sci." Bull., Series D 75.4 (2013).

[13] Rajam, Ch Venkata, et al. "Design Analysis and Optimization of Piston using CATIA and ANSYS." International Journal of Innovative Research in Engineering \& Science 1.2 (2013): 41-51.

[14] Silambarasan, R., S. Balakrishnan, and A. Selvarasu. "Design and thermal analysis of partial ceramic coated piston of spark ignition (SI) Engine." Young 19: 103. 
Computational Analysis of Reciprocating Compressor Piston Hiren Leuva, S A Shah, H A Bhargav

[15] Anusha, G., and K. Mohan Krishna. "Modeling and Analysis of Piston Design through Pro/E \& ANSYS." (2015).

[16] Khurmi, R. S., and J. K. Gupta. Theory of machines. Eurasia, 1976

[17] Bhandari, V. B. Design of machine elements. Tata McGraw-Hill Education, 2010 